Magdalena Anna RaWA

SWPS University, Warsaw, Poland

\title{
DEATH PENALTY AS A SPECIAL TYPE OF PUNISHMENT IN THE CONTEXT OF HUMAN RIGHTS
}

\begin{abstract}
The aim of the article is to show the death penalty as a special form of punishment functioning in international human rights documents. The first part of the article is devoted to the characteristics of punishment as such. General objectives and punishment functions are shown. The second part presents types of penalties functioning in the Polish legal system. The last part of the article contains a brief overview of issues related to the functioning of the death penalty in basic documents regulating human rights.
\end{abstract}

KEYWORDS: punishment, death penalty, human rights

\section{THE CONCEPT, OBJECTIVES AND FUNCTIONS OF PUNISHMENT}

Punishment, in the course of the development of societies, have been defined in a variety of ways. In ancient societies, depending on the perception of crime, it was understood as revenge of the gods or private revenge, or public retaliation, or a means of social defence. In the historical process, views on the nature and purpose of punishment changed, as well as its justification. The original reaction to crime was revenge aimed at the destruction of the offender and his property, and it was not always directed against the 
perpetrator, primarily consisted in the removal of a given member from a social union by death or expulsion from the group (alienation)) (Juhacz, Zgoliński, 2014, p. 46).

In the course of social development, the punishment took the form of a material talion which consisted in inflicting the same evil on the perpetrator as he did. This principle was expressed in the words: "life for life, eye for an eye, tooth for a tooth". Over time, the material talion was replaced by a moral (symbolic) talion. It consisted in depriving the perpetrator of the part of the body which was used by him to commit a crime, or when it was impossible, symbolic condemnation was used, e.g., cutting off the thief's hand. An analogous talion was introduced as well; the perpetrator had to suffer such a punishment as he would use against a person accused of committing a crime, e.g. for false accusation (Juhacz, Zgoliński, 2014, p. 47).

With the development of humitarianism in legal systems, the punishment from a primitive social reaction turned into a state punishment, undergoing gradual rationalization. The sense of punishment (rationalization of punishment) was justified by various reasons, and the basic arguments focused on absolute (retributive), relative (utilitarian) and mixed theories (Niewiadomska, 2016).

Based on the absolute (absolute, retaliatory, retributive) theories, the meaning of punishment is payment for an act that violates vital social interests; its idea is retribution. Punishment is inflicted when a crime has been committed. The rationale of punishment is to restore the violated social order. Punishment is a charge for a crime and does not serve any other purpose; the perpetrator must atone for the crime. All other objectives which are meanwhile pursued, e.g. deterrence of potential perpetrators, or compensation to the victim, are less important. Punishment as a social response is to oppose the will of the perpetrator and cause him some spiritual or, at least, bodily ailment . It is not only moral condemnation, it affects both the honour of the perpetrator and his other goods, such as life, freedom, and property (Wróbel, Zol, 2013).

Relative (utilitarian) theories describe punishment as a deliberate influence on the perpetrator of the crime and other members of society, rejecting any retaliation. The basic purpose of punishment is to deter the offender and 
other people from committing crimes in the future. It is expressed by the maxim of Seneca: nemo prudens punit quia peccatum est, sed ne peccetur (no one who is prudent punishes because a crime has been committed, but to prevent against the crime). It is not the crime that is punishable but the perpetrator to deter him from committing a crime. Punishment is a means to meet utilitarian objectives, namely to prevent crimes. Punishment should not be an end-in-itself, but should be aimed at ensuring that the perpetrator (individual prevention), or others, (general prevention) do not descent into crime in the future. Among these theories, depending on the preferred type of prevention, there is special prevention theory and general prevention theory. The first one assumes that the punishment is for the benefit of the perpetrator alone since it is supposed to lead to his improvement, which will deprive him of the opportunity to commit another crime. In the theory of general prevention, punishment is justified by social good. Its purpose is to deter people from committing crimes, but it does not refer to the perpetrators, but other members of society (Wróbel, Zoll, 2013).

Mixed theories recognize that punishment is a retribution and at the same time meets a preventive purpose; general and individual. Punishment consists of two elements: equity (meritum) containing retaliation, and utility (utilitas) which constitutes a teleological element of punishment. Punishment is a retribution, but purposeful one. This approach to punishment is currently dominant (Pohl, 2015). The jurisprudence argues that: "Achieving general preventive objectives by using the social impact of punishment should not be at the expense of justice. Imposing too severe penalties not only does not strengthen respect for the law, trust in the advisability of compliance with legal norms organizing society or trust in law enforcement bodies, but on the contrary, it can cause involuntary compassion of society for a criminal who is punished too severely (Judgment in the Court of Appeal in Cracow...).

The doctrine distinguishes formal and material definition of punishment. According to the first one, punishment is a legal consequence of a crime, and the second one emphasizes the meaning of punishment as an ailment suffered by the perpetrator in response to the crime. However, some experts of the subject believe that it is necessary to refer to both formal and material requirements (Stefański, 2009). 
Given the above, it can be concluded that punishment is a measure characterized by the following (Stefański , 2009):

- It is imposed by a court on behalf of the state, and the court rules on behalf of the Republic of Poland (Article 174 of the Polish Constitution); cannot be measured by another authority (nulla poena sine iudicio),

- It is imposed for a crime; punishment is a legal consequence of a crime and an element of its definition (nullum crimen sine poena); it is retaliation against the perpetrator for committing the crime,

- It is individual (personal); punishment is imposed and enforced against the perpetrator of a crime, not against another person; serving the punishment of the convict is an offense under Article 239(1) of the Penal Code (PC), and organizing a collection for paying a fine is an offense under Art. 57(1) of the Petty Offences Code (POC),

- It inflicts physical or mental discomfort on the perpetrator; consists in sensual suffering of the perpetrator, or its deprivation or limitation to a specific good, e.g. freedom, property.

The literature indicates that the content of punishment is an ailment resulting from deprivation or limitation of the goods of the person on whom the punishment was imposed, the purpose of punishment is what the punishment aims to achieve, e.g. improvement of the perpetrator; the functions of punishment are the actual effects caused by the punishment. The purpose of punishment is a postulated function. The core of punishment is determined by its content and objectives (Pohl, 2015).

The objectives and functions of punishment differ primarily in the point of view of punishment; if we look at it through the prism of what is to be achieved, we talk about the purposes of punishment, and when the subject of knowledge is what the punishment has fulfilled, we are dealing with the functions of punishment. The objectives and functions are therefore closely related.

Nowadays, rationalization of justice and purpose is considered as justification of punishment. The objectives of punishment can be reconstructed from Article 53(1) and Article 54(1) of the Penal Code (hereinafter referred to as PC). It says that punishment pursues the following objectives (Juhacz, Zgoliński, 2014, pp. 50-51): 
- justice expressed in the fact that the punishment must be commensurate with the severity of the crime. Punishment is not only a payment for a crime, but also a means to protect legal rights and prevent their violation. Retaliation is not an end-in-itself, but - as one of the purposes of punishment - is reflected in reality. The penalty constitutes "payment" for a crime (retributive justice) and is imposed in proportion to crime severity (distributive justice). It is about the commensurability of punishment to the degree of guilt and social harm of the act (Article 53(1) of PC);

- individual (special) prevention consisting in preventive and pedagogical impact on the perpetrator of a crime. Although the punishment causes the perpetrator to suffer an ailment, it is a secondary element. These objectives can be achieved by short-term imprisonment and other punishment, depending on the personality of the perpetrator and the need for pedagogical impact. Individual prevention is implemented through: elimination, improvement and deterrence.

The elimination aims to actually remove the perpetrator from the conditions that enabled him to commit a crime. Undoubtedly, this objective is fully achieved by death penalty, referred to even as elimination penalty, and this objective dominates in some punishments. The jurisprudence emphasizes that: "Twenty-five-year imprisonment is punishment of an eliminatory nature. Its primary objective is not resocialisation of the perpetrator. It is difficult to convincingly prove that a person who is not susceptible to the social rehabilitation impact of serving a sentence for a period of 15 years will undergo a positive change after a period of only 25 years (judgment of the Court of Appeal in Lublin ...). The elimination objective is also pursued by some criminal measures, namely the ban on taking a specific position, performing a specific profession or conducting a specific business activity (Article 41(1)(2) of PC) and the driving ban (Article 42(1-4) of PC), because they cause the offender to be removed from conducting the banned social activity, and thus deprive him of the possibility of committing the same crime that is committed in particular circumstances in which the offender finds himself (Stefański, 2009). 
Preventive effect aims at improvement of perpetrator, i.e. to prevent the perpetrator from committing the crime again and it leads to a juridical improvement, consisting in such psychological experiences that will stop the perpetrator from committing another crime and will have a moral effect, and is supposed to cause moral improvement, causing profound changes in the perpetrator's personality, strengthening the conviction of the validity of the applicable law, leading to the reconstruction of his moral values (Stefański, 2009).

The deterrent effect on the perpetrator consists primarily in violating his specific goods. Fear is supposed to be an incentive for the perpetrator to refrain from criminal conduct; its purpose is to act as a strong mental "brake". General (overall) prevention includes preventive effects on society. It is supposed to be a brake that prevents the general public from committing crimes. Punishment acts as a deterrent to others who, while observing the convict, become aware of the effects of punishment. It does not consist in simple deterrence, which was the purpose of punishment in the Middle Ages (justifying public executions of perpetrators of crimes), but in shaping the legal awareness of the society through the risk of punishment and its imposition. The overall preventive impact may consist in deterrence and improvement (Stefański, 2009).

The compensation purpose of punishment implies repairing the damage caused by crime and giving satisfaction to the victim. It gains in importance, which can be seen above all in the so-called consensual ways of closing criminal proceedings, e.g. conviction without trial (Article 335 and Article 343 of the Code of Criminal Procedure), voluntary submission to penalty (Article 387 of the Code of Criminal Procedure), when reconciliation of the offender with the injured party and compensation for damage are of vital importance. In addition, when imposing a penalty, the court also takes into account the positive results of mediation between the injured party and the perpetrator, or the settlement reached between them in proceedings before the court or the prosecutor (Article $53 \$ 3$ of the Penal Code). This objective is pursued, among others, by a criminal measure in the form of a duty to redress damage caused (Article 46 of the Penal Code). These objectives are highlighted in the restorative justice system, in which the focus is not 
on the perpetrator, but on the conflict (for the sake of the victim); it refers to settlement of the conflict, whereby compensation to the victim leads to forgiveness (Stefański, 2009).

These objectives are realised to varying degrees at the various stages of applying punishment. Punishment fulfils the above-mentioned objectives to varying degrees depending on whether it is a threatening, imposed or enforced penalty. Within the framework of the statutory penalty (statutory risk), general prevention plays a decisive role; in the judicial punishment all the objectives must be taken into account, while in the process of penalty execution, especially individual prevention must be considered.

\section{Types of PENALTiEs}

The penalties envisaged in the applicable penal code can be divided into non-custodial [non-isolation] penalties, i.e. those which are not related to effective imprisonment (such as fines and punishments of restriction of liberty), and isolation penalties by which the convicted person is deprived of liberty (e.g. 1 month - 15 years imprisonment, 25 years imprisonment and life imprisonment). A special isolation punishment applied only to soldiers is the punishment of military detention (Warylewski, 2017).

A fine is a punishment whose ailment consists in the depletion of the convict's property. This penalty is listed first in the catalogue of penalties in Article 32 of PC, which constitutes an indication to the adjudication court that the legislator considers this penalty as a punishment, abstractly the mildest, and also that it should be adjudicated in all cases when resorting to more severe punishments is not necessary (Warylewski, 2017).

Second to the fine, non-custodial penalty, is the penalty of restriction of liberty introduced to Polish criminal law in 1969 (Warylewski, 2017). This punishment, especially in the form of working for socially useful purposes, is becoming popular both in many European countries and in the United States, because it has the potential to significantly reduce the application of shortterm liberty deprivation against perpetrators who pose no threat to society and therefore require isolation (Warylewski, 2017). This penalty may also be an alternative to a fine that is difficult to enforce. This penalty is free of the 
defects related to imprisonment, in particular the high cost of carrying out the penalty, isolation from the family and work environment, demoralizing influence of the prison environment. The penalty of restriction of liberty, especially in the form of unpaid socially useful work, is a personal ailment, primarily affecting the perpetrator himself. In this respect, this penalty has an advantage over a fine (Wróbel. Zoll, 2013).

The core of the liberty restriction penalty is imposing restrictions on the convict, which limit his freedom in the manner specified in the Act. According to Article 34(2), the liberty restriction penalty implies the necessity to always obtain the court's consent to change the place of permanent residence; the convict is obliged to provide explanations regarding the course of serving his sentence (Act of 6 June 1997 ...).

Listed in Article 32(3) of the Penal Code (Act of June 6, 1997...) imprisonment, unlike the penalty of 25 years and life imprisonment, is referred to as deprivation of liberty for a fixed term. According to Article 37 of PC, imprisonment may not be shorter than one month or longer than 15 years. It is adjudicated in months and years.

In most types of offenses, the foreseen penalty is only a prison sentence. These are penalties up to 3 years, from 3 months to 5 years, from 6 months to 8 years, from 1 year to 10 years, from 2 years to 12 years and from 3 years. If the lower or upper penalty limits are not mentioned in the specific part, the limits provided for in Article 37 of PC for imprisonment apply. Therefore, in the event of a penalty of imprisonment up to 3 years, this penalty ranges from one month to 3 years, and in those cases when the law introduced the penalty of imprisonment not less than 3 years and no more than 15 years (Wróbel. Zoll, 2013).

Imprisonment can be also an alternative to a 25 -year imprisonment sentence. In this case, the lower limit for a fixed-term imprisonment is 5 years, and as an alternative to both the most severe sentences ( 25 years or life imprisonment) and then the lower limit is 8,10 or 12 years. In all these cases, the upper limit for the punishment of fixed-term imprisonment is 15 years (Wróbel. Zoll, 2013).

The penalty of life imprisonment is the most severe of the penalties provided for in our system. It is envisaged as an alternative punishment, 
likewise the penalty of deprivation of liberty for a fixed term (from 8,10 or 12 years) and the penalty of 25-year imprisonment. In a single case, which is today of historical significance, the penalty of life imprisonment is the only penalty for the crime of genocide set out in Article 1 of the Decree of 31 August 1944 on the severity of punishment for Nazi criminals guilty of murder and mistreatment of civilians and prisoners and for the traitors of the Polish Nation (Journal of Laws of 1946. No. 69, item. 377 as amended). Originally, the only sanction provided for the crime referred to in Article 1 of the Decree was death penalty. Pursuant to Article 13(1) of the Act of 6 June 1997 - Implementing provisions of the Penal Code - the death penalty envisaged in the decree was replaced by life imprisonment (Wróbel, Zoll, 2013).

In May 2019, the Sejm adopted an amendment to the Penal Code. It illustrated a new punishment philosophy represented by "PiS" (Polish political party, translated as "Peace and Justice"). Generally speaking, it involves aggravation of the punishment system. In line with this amendment, the penalty of 25-year imprisonment for the most serious crimes was abolished, and 30 years was introduced instead. These changes also apply to life imprisonment. Courts were required to issue a prohibition of conditional release if the perpetrator has already been sentenced to a prison for not less than 20 years and if the nature and circumstances of the act and the characteristics of the offender indicate that he may pose a permanent danger to others. The period after which a prisoner sentenced to life imprisonment will be allowed to apply for conditional release was increased from 25 to 35 years. The amendment introduced the penalty of life imprisonment without parole. It was destined against perpetrators who are permanently dangerous to society. The amendment also introduced to the Penal Code new types of offenses, some of which were not yet punishable at all, even though they were socially harmful. These include: preparation for committing murder, which is under the penalty of 2 to 15 years of imprisonment; acceptance of the order to commit a murder - under the penalty of $2-15$ years of imprisonment; evasion of the compensation for damage caused by a crime - under the penalty of 3 months to 5 years of imprisonment (today only under the penalty of bailiff execution), audacious thievery, e.g. pickpocket or 
when a thief snatches a purse on the street - under the penalty of 6 months to 8 years of imprisonment regardless of the value of the stolen item (Draft act amending the act ...).

The amendment was criticized by the legal community. In addition to substantive allegations, the unconstitutional procedure for adopting the amendment was alleged, which may lead to its questioning by courts and procedural parties (158 scientists write...). Ultimately, President A. Duda did not sign the Act and sent it to the Constitutional Tribunal. According to the Chancellery of the President, this decision is "justified primarily by the analysis of the legislative procedure" (the President directs the amendment...).

\section{DEATH PENALTY IN THE CONTEXT OF HUMAN RIGHTS}

The death penalty as a special type of punishment is a subject that has been discussed many times within the fields of philosophy, religion, ethics and law. One of the particularly important threads of disputes on the issue of the death penalty is the relationship between this type of punishment and the human rights functioning in the modern world.

The right to life is the most fundamental human being' s entitlement. On the other hand, the immanent feature of the death penalty is its irreversibility. Therefore, it is not possible to reinstate a violation of the most important right that every human being has. The problem of the possibility of capital punishment in the context of the right to life is present not only at the axiological and preventive (deterrent) level, but also in the aspect of international law, which is increasingly accentuated. Moreover, it is impossible to talk about the death penalty, leaving aside philosophical and legal-philosophical issues. They seem to be the foundation of disputes over the possibility of the State depriving a person of their life legally, while the dogma of the law is equally important, but always secondary. There is no doubt about the absolute, natural, inalienable and universal nature of the right to life, but the scope of it remains a controversial issue until today, also in the context of the main subject of this article, which is the death penalty in relation to human rights. 
To claim that life is of great value to every human being would be a truism, but to believe that it has the highest value is, in my opinion, controversial. Nowadays, there is a philosophical dispute between the supporters of the importance of life in its absolute sense and the protagonists - those who declare the need for relativism concerning this issue. Such a problem arises when a State authority allows for the application of the killing agent to a person, for example, in the form of the death penalty, abortion, euthanasia, or even when it authorises the law enforcement services to be given too much power (for example, to use live ammunition during demonstrations).

Currently, there is no universally accepted definition of human rights. Among many terms used, the definition of the Polish Red Cross can be cited: "Human rights are a set of norms of both international law and internal law, which ensure that each human being has the opportunity to exist and act in a way that corresponds to the inherent and inalienable dignity of an individual as a member of the human community by having granted the access to specific material and spiritual goods and the freedom to behave in a specific way, as well as by prohibiting people from interfering with the exercise of their rights and freedoms "(Sokołowski 2004, p. 11). Wiktor Osiatyński, in turn, says that "Human rights are universal moral rights of a basic nature, belonging to every individual in their interaction with the state" (Osiatyński, 2011, p. 67.). Z. Hołda, on the other hand, defines human rights as "particularly momentous rights that serve an individual according to some philosophical concept, referring to their position in the state or in the light of national law" (Hołda, 1996, p. 3).

The term "individual dignity" is closely related to the concept of human rights ("dignity of the human being" according to the Catholic Church). It is similar to the term "personal dignity", which is defined in terms such as honour, pride and good name. Personal dignity is associated with the core of humanity and it is inalienable; it cannot be lost, every human has it for the reason of being a human alone (Mrozek, 2014, pp. 41-42).

In turn, this concept derives two others: freedom and equality. The first one, depending on the idea may mean freedom from the state, as was the case in the United States of America, when the state plays only the role of a "night watchman", protects against internal and external enemy or, as in Europe, 
freedom through the state. The second one has also different meanings - it can mean either equal benefits due, living conditions, or equal opportunities, or equal rights (close to non-discrimination) and equality before the law.

In the Universal Declaration of Human Rights, adopted on 10 December 1948 by the UN General Assembly, the introduction reads: "recognition of the inherent dignity and the equal and inalienable rights of all members of the human community is the basis of freedom, justice and peace in the world" (Universal Declaration ...), whereas Article 1 states that "All people are born free and equal in dignity and rights. They are endowed with reason and conscience and should act towards others in a spirit of brotherhood "(Universal Declaration ...).

The World Conference on Human Rights in the Vienna Declaration of June 1993 stated that "All human rights are universal, indivisible and interdependent and interrelated. The international community must consider human rights as a whole, in a fair and equal manner, on the same level and with equal attention "(Vienna Declaration ...).

The right to life is a part of every document that contains general human rights standards and is consolidated in some special conventions. This right is always put first when opening the catalogue of rights protected under a given document. The order in which a certain law is regulated has no direct legal significance; however, it is a kind of symbol. The right to life is a premise and a necessary condition for exercising other human rights (Jasudowicz, 2010).

In connection with the guarantees of the right to life (variously outlined in the documents regulating this issue), the problem of the deprivation of life occurs. This leads to the issue of the admissibility of the death penalty. The International Covenant on Civil and Political Rights (ICCPR) (International Covenant on Civil Rights ...) deals with this issue very extensively, raising the issue of the exceptional admissibility of the death penalty, restrictions on its use and the rights of persons sentenced to such a penalty (Article 6(2-6)). In contrast, the European Convention for the Protection of Human Rights and Fundamental Freedoms (ECHR) (Convention for the Protection of Human Rights ...) deals with the problem more concisely, stipulating that there is a prohibition on the deprivation of life, subject to "cases of enforcement 
of a court decision sentencing for an offense for which the law provides such a penalty "(Article 2(1) sentence II in fine ). Both documents refer only to strictly legally regulated death penalty and its lawful application, with full respect for the guarantee of the right to a fair trial and the prohibition of the retroactive application of criminal law. It is worth mentioning that also in relation to hostilities, the admissibility itself as well as the guarantees regarding the method of administering the death penalty are strongly confirmed in Article 101 of the III Geneva Convention (III Geneva Convention) and Article 68 of the IV Geneva Convention (IV Geneva Convention)).

The Geneva Convention clearly restricts the admissibility of the death penalty only to "the most serious crimes", stipulating compliance with its provisions and the provisions of the Convention on the Prevention and Punishment of the Crime of Genocide. However, the Human Rights Committee allows the death penalty in the case of mass murders or crimes committed with particular cruelty (Bartusiak, 2011). The material scope of admissibility of the death penalty is therefore significantly narrowed in this case.

The personal scope of admissibility of the death penalty was also limited, in terms of its application or execution. According to Article 6 Clause 5 of ICCPR, the death penalty may not be applied to a person who was under 18 years of age at the time of committing the crime. Therefore, the use of the death penalty against children, including minors, is ruled out (see also Article 37 "a" of the Convention on the Rights of the Child [Convention on the Rights of the Child]; also Article 68 in fine IV of the Geneva Convention).

Under the Geneva Convention, the death penalty against a pregnant woman is ruled out. It is contained in the formula: "Death sentence ... will not be carried out [...]" (Geneva Convention). In 1977, Additional Protocols to the Fourth Geneva Convention, in Article 76(3) not only stipulates that "the death sentence against such women (not only "pregnant" but also "mothers caring for young children ") is not enforceable, but also obliges states to make every effort "that the death penalty is not adjudicated (against them)" (Additional Protocol). Thus, in international humanitarian law, earlier than in international human rights law, this personal limitation on the admissibility of adjudication and execution of the death penalty had been significantly expanded. 
The UN Economic and Social Council in its resolution of 1984 ruled out the death penalty also for mothers of young children, as well as "insane people" (Safeguards Guaranteeing Protection...). It can be mentioned that the American Convention on Human Rights rules out the death penalty against persons who were at the age of 70 at the time the offense was committed (Article 4 (5)) (American Convention ...).

It should be emphasized that sentencing someone to death, even when the sentence is final, does not mean that (s)he has lost the right to life. ICCPR states in Article 6(4) that "Everyone sentenced to death has the right to apply for clemency or to change the sentence" - even "in all cases" (Journal of Laws of 1977 No. 38, item 167). The application of the prerogative of mercy is also envisaged during armed conflict (see Article 75 IV of the Geneva Convention). The international human rights law prohibits immediate or accelerated executions. The consequence of recognizing the prerogative of mercy is also recognizing the fact that execution cannot be enforced while the proceedings related to the exercise of this right are in pending.

The literature on the subject points out that persons sentenced with final validity to the death penalty still have rights resulting from other human rights and, as a rule, must be treated on an equal footing with other prisoners. In a sense, it can be even argued that the phenomenon of so-called positive discrimination, i.e. privileged treatment, e.g. in the sphere of satisfying their spiritual needs or contacts with the immediate family, is applied to such people (Jasudowicz, 2010).

Protocol VI to the ECHR of 1983 abolishes the death penalty, so it cannot be imposed by court. It also rules out the enforcement of previously issued death sentences (Article 1) (Convention for the Protection of Human Rights). This prohibition is classified as an indefeasible right, likewise the right to life itself (Article 3). However, this prohibition is not absolute. Article 2 allows the state to retain the death penalty "for acts committed during war or imminent threat of war" (Convention for the Protection of Human Rights ).

An similar ban, based on the ECHR, was introduced by the Second Optional Protocol to the ICCPR in 1989 (Second Optional Protocol). In this context, it should be noted that at present all (except Russia) States Parties to the ECHR are bound by Protocol VI (Poland in 2000), while less than $1 / 3$ of 
States Parties to the ICCPR are bound by the Second Optional Protocol. It shows that most countries in the world do not rule out the use of the death penalty. Some countries, also in Europe, using the possibilities offered by Article 2 of Protocol VI, do not preclude the use of this penalty in the context of war (Hołda Z., Hołda J., Ostrowska, Rybczyńska, 2014).

Under Protocol XIII to the ECHR, a ban on the use of the death penalty "in all circumstances" (Article 1) was adopted, which in practice implies the elimination of the abovementioned Article 2 of Protocol VI. This extended prohibition has been given the character of indefeasible right (Article 2) (Journal of Laws of 2014, item 1155).

It should be emphasized that the legal regulations of the European Union regarding the possibility of using the death penalty are unambiguous. In art. 2 of the Charter of Fundamental Rights not only states that "Everyone has the right to life", but also prejudges in its second paragraph that "Nobody can be sentenced to death or subjected to its execution" (Charter of Fundamental Rights). Taking into account the content of Article 52(3) of the Charter, which defines that the rights contained in the Charter of Fundamental Rights have the same meaning and scope as the corresponding rights contained in the Convention (understood jointly with the protocols), it can be concluded that the statement on the total prohibition of the death penalty in the European Union is obvious (Wieruszewski, 2010).

An important issue related to the death penalty in the context of human rights is the problem of the relationship of this institution as well as the regulations allowing the use of the death penalty in international human rights documents, as an exception to the guarantee of the right to life to a norm prohibiting torture and inhuman or degrading treatment. It is important to control the way in which the death penalty is exercised, e.g. waiting period for execution. The UN Human Rights Committee in the commentary on Article 7 of ICCPR, announced in 1992, stated that in the event of executing death penalty by a State, the execution must be carried out in a way causing the least possible physical and mental suffering to the convict (Wieruszewski, 2012).

In 1990, a document abolishing the death penalty within the American human rights system (American Convention on Human Rights) was adopted. Its content is similar to the Second Optional Protocol of ICCPR. 
However, it more robustly prohibits both the execution and the imposition of the death penalty against persons subject to the jurisdiction of States Parties. In a manner similar to the Second Optional Protocol of the ICCPR, the American document introduces the formula of a reservation by a State which allows the death penalty during war (Article 2). This document also requires the death penalty to be in accordance with international law. Similarly to the Second Optional Protocol of the ICCPR, the death penalty can be adjudicated during war only for the most serious military crimes. However, the American document does not specify the time of committing the crimes for which the death penalty may be imposed during the war (Lang, 2015, p. 128).

The possibility for the State to carry out the death penalty is not only a legal problem, but also a philosophical one. The fundamental question arises: does the State have the right to kill a person under the law if it is not a self-defence? Furthermore, one can also ask: is any murder under the law morally wrong? It seems that the answers to these questions will polarise scientists (above all, ethicists and lawyers).

It is often mentioned in the discussions that, if the death penalty violates the right to life, the right to liberty, which is also a human right, would likewise be violated by imprisonment. Such a claim would be legitimate if we put a sign of equality in the hierarchy between these two human rights. Moreover, while the violation of the right to liberty or property may be reversible, the violation of the right to life is absolutely irreversible.

The authorities of the modern States must answer the question of the scope of the right to life. It should be noted that the bodies which guard the implementation of States' international obligations very often combine the right to life with an access to health care. A similarly wide interpretation of this provision is given by the European Court of Human Rights, which, in its verdicts, has repeatedly linked the functioning of health services in a given country to the right to life. Furthermore, the Convention on the Rights of Persons with Disabilities, which, in Article 10, recalls the right to life, obliges all States Parties to take the appropriate measures to effectively enforce this right on an equal basis for all the citizens. It can be agreed that the individual's right to water is also a consequence of guaranteeing the right to life. It is true 
that a lack of access to water does not mean a direct violation of the right to life, but deliberately depriving someone of water, for example, by the State authorities, would indirectly infringe this right.

Neither international law nor national laws of any particular country answer the following questions:

1) what to do if the death penalty has a real deterrent effect?

2) what to do if the human rights must be violated in order to save the lives of others? (e.g. when the only way of investigating is to use torture to get information where a bomb will explode that will kill many innocent people).

Such unsolvable ethical and legal problems will continue to exist as long as an absolute and inalienable nature of the human rights is present. Let us consider for a moment what would happen if we allowed the State authorities to break human rights in certain specific situations in order, for example, to get information to save many innocent people. Those who support the opinion that "the end justifies the means" will approve such an action and consider it right and advisable. However, the opponents of treating human rights in a relative way will certainly argue in two ways. Firstly, allowing a specific human right to be violated in a certain situation may create a dangerous precedent that the State will be able to do so in any subsequent similar situation. Secondly, if a State can break human rights in one situation, why not to do so in another? As a result, it could turn out that human rights are violated in so many cases that their nature and purpose would become a fiction. Consequently, we are doomed to remain in an ethical and legal impasse, which is anyway safer than if we were to resolve it by abolishing the inalienable and absolute nature of human rights.

Despite the different interpretations of the right to life, it should be noted that today's European legislators combine it strongly with the prohibition of the death penalty. This applies to the construction of legal provisions in such a way that the law is standardised alongside the article prohibiting the imposition and execution of the death penalty. This legal and editorial procedure is not accidental or purely stylistic. The legal provision on the right to life is located in the legislative editorial unit directly above the provision 
prohibiting the death penalty. As a result, the capital punishment prohibition is an obvious consequence of this most fundamental human right.

The European trend towards a wider interpretation of the right to life and the elimination of the death penalty in every case draws attention. According to the courts and tribunals of the modern European countries, there is no doubt that the execution of the capital punishment is connected with a violation of the right to life. It is worth looking at federal law and the legislation of individual states in the USA on the application of the death penalty. Today, we can see that at federal level and in most states, the death penalty is still standardised. To be honest, it should be pointed out that only in a dozen or so states is the penalty still being carried out, because in the other states it has either been abolished or there is a moratorium. If we accept the universal nature of human rights and its interpretation, which the courts and tribunals of Western European and EU countries would probably apply, we would have to recognise that the United States of America violates the right to life (from the point of view of European law). In the US Constitution there are two controversial laws that could prohibit the death penalty, Amendments VIII and XIV (Laidler, 2007).

It should not be forgotten that the European abolitionist trend discussed earlier completely ignores the significant claim that Priest $\mathrm{T}$. Ślipko cites in his book Death Penalty: For or Against: "[...] with the death of the victim of aggression, their moral right to life and to the self-defence does not come down to their grave" (Ślipko, 2010). Therefore, the State would have a moral obligation to extend the right of self-defence of a person who has already been murdered ${ }^{1}$, that is to say, whose right to life has been denied by another individual in an arbitrary and unfair manner.

The scope of human rights, with its absolute, natural, inalienable and universal nature, has been repeatedly reinterpreted. These features are not subject to discussion, but the width of their interpretation remains a contentious issue, such as the interpretation of the right to life in the context of the imposition and execution of the death penalty. It seems that there are too many different interpretations of the range of the right to life in the world, and therefore it is not easy to find a compromise from this perspective. The problem is compounded by the fact that many rulers in the 
modern world claim the right to make sovereign and ambitious laws on their own territory in an isolation from any international regulations.

It should be noted at this point that human rights legislation deals with the problem of the death penalty in general terms. In additional documents relating directly to the main penalty, despite the explicit prohibition on its use, there are numerous concessions. It is a paradox that the United States, as a democratic country with anthems on freedom, is at the top of the list of countries that execute the death penalty. Suggesting to the opinion of the public is not a positive solution. The United States, as a strong country, does not need to apply the act of self-defence and consequently to classify its approach to this issue together with China or Iran.

The significant development of the idea of human rights after the Second World War must be considered a positive phenomenon. It should be noted, however, that it is possible to understand these rights in different ways. As far as the death penalty is concerned, the international documents cited above show a tendency towards the abolition of this penalty.

In the context of human rights legislation, it should be noted that the criteria adopted by the authors of these documents are unclear. The process of abolishing the death penalty has simply been attributed a positive value. Many times, there are references to abolitionist tendencies as something positive in human rights documents. It seems reasonable, therefore, to assume that the main argumentation is deeper, and when considering the discussions on the philosophical establishment of human rights, there is still, despite the emergence of relativism, a reference to the Enlightenment's ideas of progress.

While recognising the unquestionable value of human life, which never loses its value, it should not consider the acceptability of the right to abortion, let alone the recognition of the right to abortion as a woman's birthright; because the discussion is taking place at the moment when human existence begins, therefore, it should be interpreted in dubio pro reo in an extended version. What must be surprising is that the doubts about someone's fault are judged in favour of that person, and the doubts about the existence of a human being are judged against them. The more surprising it is that we can observe a legal state in which nasciturus has certain conditional property rights, but not their unconditional right to life. 
The concept of human rights is closely related to human dignity. It can be said that this dignity is a kind of constitutive principle of any judgment. However, what does this special human dignity mean? There are at least two elements which are connected with the dignity of the human being: reasonableness and freedom (free will). These elements, in turn, enable one to take responsibility for their own actions. A fair punishment is, therefore, a respect for human dignity, not a violation of it.

\section{Bibliography}

\section{Legal acts}

Dekret z dnia 31 sierpnia 1944 r. o wymiarze kary dla faszystowsko -hitlerowskich zbrodniarzy winnych zabójstw i znęcania się nad ludnością cywilną i jeńcami oraz dla zdrajców Narodu Polskiego [Decree of 31 August 1944 on punishment for fascist-Nazi criminals guilty of murder and ill-treatment of civilians and prisoners of war, and for traitors to the Polish Nation], Journal of Laws of 1946 No. 69, item 377 , as amended.

Drugi Protokół Fakultatywny do Międzynarodowego Paktu Praw Obywatelskich i Politycznych w sprawie zniesienia kary śmierci, przyjęty w Nowym Jorku dnia 15 grudnia 1989 r. [Second Optional Protocol to the International Covenant on Civil and Political Rights on the abolition of the death penalty, adopted in New York on 15 December 1989], Journal of Laws 2014, item 891

Karta Praw Podstawowych Unii Europejskiej [Charter of Fundamental Rights of the European Union], Official Journal of the EU 2016 C 202.

Konwencja o ochronie praw człowieka i podstawowych wolności z 4.11.1950 r. [Convention for the Protection of Human Rights and Fundamental Freedoms of 4.11.1950], Journal of Laws of 1993 No. 61, item 284, as amended.

Konwencja o prawach dziecka z 20.11.1989 r. [Convention on the Rights of the Child of 20.11.1989], Journal of Laws of 1991 No. 120, item 526, as amended.

Międzynarodowy pakt praw obywatelskich i politycznych z 19.12.1966 r. [International Covenant on Civil and Political Rights of 19.12.1966], Journal of Laws of 1977, No. 38, item 167.

Protokół nr 13 do Konwencji o ochronie praw człowieka i podstawowych wolności dotyczącego zniesienia kary śmierci we wszystkich okolicznościach, sporządzony w Wilnie dnia 3 maja 2002 r. [Protokol No. 13 to the Convention for the Protection of Human Rights and Fundamental Freedoms concerning the abolition of the death penalty in all circumstances, drawn up in Vilnius on 3 May 2002]. 
Protokół Nr 6 do Konwencji o ochronie praw człowieka i podstawowych wolności, dotyczący zniesienia kary śmierci, sporządzony w Strasburgu dnia 28 kwietnia 1983 r., Dz.U. 2001 nr 23 poz. 266. [Protocol No. 6 to the Convention for the Protection of Human Rights and Fundamental Freedoms, concerning the abolition of the death penalty, drawn up in Strasbourg on April 28, 1983, Journal of Laws 2001 No. 23 item 266].

Ustawa z dnia 6 czerwca 1997 r. - Kodeks karny, t.j. Dz. U. z 2018 r. poz. 2077 [Act of June 6, 1997 - Penal Code, i.e. Journal of Laws of 2018, item 2077].

\section{Jurisdiction}

Judgment of the Court of Appeal in Lublin of April 6, 2006 , II AKa 65/06, Prz. Orz. PA, in Lublin 2006, No. 36, item 36.

Judgment of the Court of Appeal in Krakow of February 1, 2001, II AKa 3/01, KZS 2001, No. 2, item 22.

\section{Literature}

Bartusiak B. (2011), Kara śmierci w świetle sporu o racjonalizację kary śmierci [Death penalty in the light of the dispute on the rationalization of the death penalty], Warszawa: C.H. Beck. ISBN 9788325512835.

Hołda Z. (1996), Ochrona praw człowieka [Protection of human rights], Lublin: UMCS. ISBN 832270951X.

Jasudowicz T (2010)., Prawo do życia [Right to life], [in:] B. Gronowska i in., Prawa człowieka i ich ochrona [Human rights and their protection], Toruń: TNOiK. ISBN 9788372855060.

Juhacz W., Zgoliński I. (2014), Aktualny model kary pozbawienia wolności i jego perspektywy, Studia z zakresu nauk prawnoustrojowych. Miscellanea nr 4. [Current model of imprisonment and its perspectives, Studies in the field of Law Sciences. Miscellanea No. 4]. ISSN 1899-4601.

Lang M. (2015), Kara śmierci a prawa człowieka, Studia z zakresu nauk prawnoustrojowych. Miscellanea, nr. 5 [Death penalty and human rights, Studies in the field of legal systems. Miscellanea, No. 5]

Mrozek J.J. (2014), Godność osoby ludzkiej jako źródło praw człowieka i obywatela, Civitas et Lex, nr 1. [Dignity of the human person as a source of human and citizen rights, Civitas et Lex, No. 1]. ISSN 2449-5522.

Niewiadomska I. (2016), Osobowościowe uwarunkowania skuteczności kary pozbawienia wolności [Personality determinants of the effectiveness of imprisonment], Lublin: KUL. ISBN 9788373635722. 
Osiatyński W. (2011), Prawa człowieka i ich granice [Human rights and their limits], Warszawa: Wydawnictwo Znak,. ISBN 9788324015139.

Pohl Ł. (2015), Prawo karne: wykład części ogólnej [Criminal law. Lecture of the general part], Warszawa: Wolters Kluwer. ISBN 9788326494109.

Sokołowski T (2004)., Międzynarodowa ochrona praw człowieka: zarys [International protection of human rights. Outline]., Warszawa: WSP im. Janusza Korczaka. ISBN 8388278576.

Stefański R.A. (2009), Prawo karne materialne. Część ogólna [Substantive criminal law. General part], Warszawa: Difin. ISBN 9788372519245.

Warylewski J. (2017), Prawo karne. Część ogólna [Criminal law. General part], Warszawa: Wolters Kluwer. ISBN 9788381076876.

Wieruszewski R. (2010), Międzynarodowe zobowiązania Polski dotyczące abolicji [International commitments of Poland regarding abolition] [in:] Śmierć nie jest sprawiedliwością. Europa przeciwko karze śmierci, [Death is not a righteousness. Europe against the death penalty, Information Office of the Council of Europe], Warszawa: Biuro Informacji Rady Europy. ISBN 9788360216064.

Wieruszewski R. (2012), Międzynarodowy Pakt Praw Obywatelskich (Osobistych) i Politycznych. Komentarz [International Covenant on Civil (Personal) and Political Rights. Commentary], Warszawa: Wolters Kluwer. ISBN 9788326439339.

Wróbel W., Zoll A. (2013), Polskie prawo karne. Część ogólna [Polish Criminal Law. General Part], Kraków: Wydawnictwo Znak. ISBN 9788324021574.

\section{Internet sources:}

158 naukowców pisze do prezydenta w sprawie zmian w Kodeksie karnym. „Chaos prawny" [158 scientists write to the president on amendments to the Penal Code. "Legal Chaos"] http://www. tvn24.pl accessed February 9, 2019.

20 lat $\mathrm{w}$ walce o Twoje prawa [20 years in the fight for your rights], http://www.unic. un.org.pl/prawa_czlowieka_20lat/ accessed February 9, 2019.

Amerykańska Konwencja Praw Człowieka [American Convention on Human Rights], http://libr.sejm.gov.pl/tek01/txt/inne/1969a-c1.html accessed February 9, 2019.

Powszechna Deklaracja Praw Człowieka [Universal Declaration of Human Rights], http://www.unesco.pl/fileadmin/user_upload/pdf/Powszechna_Deklaracja_Praw_Czlowieka.pdf accessed February 9, 2019. 
Prezydent kieruje nowelizację Kodeksu karnego do Trybunału Konstytucyjnego [President sends Penal Code amendment to Constitutional Tribunal], http://www. tvn24.pl accessed February 9, 2019.

Projekt ustawy o zmianie ustawy Kodeks karny oraz niektórych innych ustaw [Draft Act on amending the Penal Code and certain other acts], https://www.premier.gov. $\mathrm{pl} /$ wydarzenia/decyzje-rzadu/projekt-ustawy-o-zmianie-ustawy-kodeks-karnyoraz-niektorych-innych-ustaw-6.html accessed February 9, 2019.

Safeguards Guaranteeing Protection of the Rights of Those Facing the Death Penalty, ESC Res. 1984/50, Safeguards guaranteeing protection of the rights of those facing the death penalty, https://www.unodc.org/pdf/criminal_justice/Safeguards_Guaranteeing_Protection_of_the_Rights_of_those_Facing_the_Death_Penalty.pdf accessed February 9, 2019.

\section{Footnotes}

${ }^{1}$ If the individual in question was alive and the only way to save their life was to deprive the aggressor of their life, then, in fulfilling their right to a self-defence, the attacked individual could legally deprive the attacker of their life, thereby protecting their own. 
